Received 15.03.2017 Reviewed 19.04.2017 Accepted 30.05.2017

A - study design

B - data collection

C - statistical analysis

D - data interpretation

E - manuscript preparation

F - literature search

\section{The technical aspects of using timber in the construction of forest roads}

\author{
Grzegorz TRZCIŃSKI ${ }^{1) \text { ACDEF }}{ }^{凶}$, Pawel KOZAKIEWICZ ${ }^{2) \text { ABD }}$, \\ Rafal SELWAKOWSKI ${ }^{3) B E}$
}

\footnotetext{
1) Warsaw University of Life Sciences - SGGW, Faculty of Forestry, Department of Forest Utilization, Nowoursynowska 159, 02-776 Warszawa, Poland; e-mail: grzegorz_trzcinski@sggw.pl

${ }^{2)}$ Warsaw University of Life Sciences - SGGW, Faculty of Wood Technology, Nowoursynowska 159, 02-776 Warsaw, Poland; e-mail: pawel_kozakiewicz@sggw.pl

${ }^{3)}$ Development and Implementation Centre of the SF in Bedoń, Nowy Bedoń, ul. Sienkiewicza 19, 95-020 Andrespol, Poland; e-mail: rafal.selwakowski@bedon.lasy.gov.pl
}

For citation: Trzciński G., Kozakiewicz P., Selwakowski R. 2017. The technical aspects of using timber in the construction of forest roads. Journal of Water and Land Development. No. 34 p. 241-247. DOI: 10.1515/jwld-20170059 .

\begin{abstract}
This study is on the ecological aspects and interest of the State Forest National Forests Holding (SF) units in reinforcing the ground subgrade by using timber raft construction and brushwood mattresses in forest road construction. The aim of the study was to analyse the technical parameters of forest roads made on a ground subgrade reinforced with timber raft construction and brushwood mattresses. As part of the research, the scope of SF units' application of technological solutions and the parameters of existing forest district roads made on a timber substructure were determined. A road with reference sections using different variants of subgrade reinforced with timbers logs (oak, pine) and brushwood mattresses were studied. The technical parameters of features ensuring usability, such as, among others, the bearing capacity of the pavement, were selected for the analysis. The ability of the tested pavements to support vehicle axle loads was determined based on the deflection of the surface as well as the primary $\left(\mathrm{M}_{\mathrm{EI}}\right)$ and secondary $\left(\mathrm{M}_{\mathrm{EII}}\right)$ deformation modulus with a calculated deformation indicator $\left(I_{0}\right)$. The deformation modulus ME of the pavement and road subgrade were determined using a VSS plate with a diameter of $300 \mathrm{~mm}$. It indicated a large range of results of secondary deformation of surfaces using timber raft construction $\left(107-204 \mathrm{MN} \cdot \mathrm{m}^{-2}\right)$ and brushwood mattresses $\left(26-58 \mathrm{MN} \cdot \mathrm{m}^{-2}\right)$, which are dependent mainly on the diameter of the logs used, their arrangement and the road fill used.
\end{abstract}

Key words: forest roads, pavement of road, reinforcement of road subgrade, road subgrade

\section{INTRODUCTION}

Road subgrades made of soils with poor bearing capacity occur most frequently in marshy areas of forests with organic soils, as well as on mineral soils over subgrade profiles with impermeable layers [MILER et al. 2007]. The area of habitats comprised of pine complex forests, forests on wet and marshy soils and alder forests in the State Forest National Forests
Holding (SF) totals 1,477,760 ha, which represents $16.1 \%$ of all forests. In 2007 , the forest districts of the SF categorized almost 264,000 ha of forest as inaccessible, and 749,000 ha as difficult to reach, in large part due to the lack of road infrastructure and difficult terrain conditions.

The authors of many studies [MARTIN et al. 1999; MiLER et al. 2007; O'MAHONY et al. 2000; TRZCIŃSKI 2011a] confirm the significant impact of road sub- 
grade on the bearing capacity of pavements of forest roads, and KAMINSKI and CZERNIAK [2001] indicate that in some cases, it causes a decline in the deformation modulus of up to $300 \%$. The road subgrade as well as the construction of forest and agricultural road surfaces must be adapted to vehicles with heavy loads. [KoZŁowSKI, SUROWIECKI 2011; TRZCIŃSKI 2011b].

Timber as a natural material is used to reinforce the subgrade [MUNRO 2004] and also in the water constructions [JEDRYKA 2007]. The method of building roads on a subbase of logs is very old in Poland. GODLEWSKI [2011] provides a description from the Middle Ages of a road built this way in Giecz, and this is confirmed by new discoveries made in Gniew and Poznań. A road from $4000 \mathrm{BC}$ on the peatlands made on timber logs was discovered in the areas of southern Ireland [MUNRO 2004]. The twentieth century provides examples of roads built on a timber base in Finland, Norway and Scotland [MUNRO 2004].

The use of timber by SF units to reinforce road subgrades was also indicated in the publication "Forest Roads: Technical Guide" [DZIKOWSKI et al. 2006]. Environmental aspects, the use of natural materials on wet soils, often in areas of natural value, as well as the interest of State Forest units in the use of reinforced subgrade material made from timber (logs, mats) was the basis for undertaking this research topic. Using timber logs in wetlands increases the accumulation of organic carbon for a longer period of time.

\section{AIM AND SCOPE OF THE STUDY}

The aim of the study was to analyze the technical parameters of forest roads made on a subgrade reinforced with timber logs (poles) or willow brushwood mattresses. Part of the research also determined the extent to which State Forest units use the technologies under discussion, as well as the parameters of the forest roads currently used in the forest districts that have a timber (log or mat) base. As part of the study, a road with reference sections was designed and constructed with different variants of subgrade reinforced with logs (oak, pine) and willow brushwood mattresses. The range of measurements included the measure of pavement deflection under load conditions, and then on this basis bearing capacity of pavement was rated, by determining the primary $\left(\mathrm{M}_{\mathrm{EI}}\right)$ and secondary $\left(\mathrm{M}_{\mathrm{EII}}\right)$ moduli of deformation and deformation indicator $I_{0}$ (level of compaction).

\section{METHODS}

Data on the extent of the quantitative and qualitative use of timber logs and willow brushwood mattresses to strengthen road subgrades by State Forests units was determined by gathering information from individual forest districts, which were then verified.

We planned to construct tested sections with pavements on subgrade reinforced with timber logs and willow brushwood mattresses on a significantly important forest road for forestry management (main transportation road) located on low bearing capacity soils in wet habitats. Proposals for the construction of the pavements took into account different reinforcement options and used aggregate.

The ability of the tested pavements to support the loads of vehicles was determined based on the deflection of the pavement and the calculated primary $\left(\mathrm{M}_{\mathrm{EI}}\right)$ and secondary $\left(\mathrm{M}_{\mathrm{EII}}\right)$ deformation moduli and deformation indicator $\left(I_{0}\right)$. The pavement deflection under primary and secondary loads was determined by using a static plate (300 $\mathrm{mm}$ diameter VSS plate) in accordance with guidelines of BN-64/8931-02 and PN-S02205: 1998 standards.

\section{RESULTS}

\section{CONSTRUCTION OF THE ROAD PAVEMENTS}

The current IT system SF does not have detailed information on roads whose subgrades are reinforced with timber logs or willow brushwood mattresses. The use of such technologies is indicated in very few cases, less than ten. Therefore, we tried to gather information on the basis of data obtained directly from the forest districts. In many cases, the road sections indicated by the forest district were skidding trails with timber logs placed on the surface and not roads with pavements constructed to carry high tonnage vehicles (Photo 1). Data from the forest districts was verified and nine forest road sections reinforced with timber logs or willow brushwood mattresses were identified for the study. Their basic characteristics are presented in Table 1.

Roads reinforced with timber logs are variously constructed, mainly during the renovation of forest roads, where fragments of roads with timber logs and with too thin layer of road fill are found (Photo 1).

Roads reinforced with willow brushwood mattresses with geotextile and aggregate layers were built under constructing by the Słupsk Maritime Office in the Ustka Forest District on soils that had low bearing capacity and were very wet.
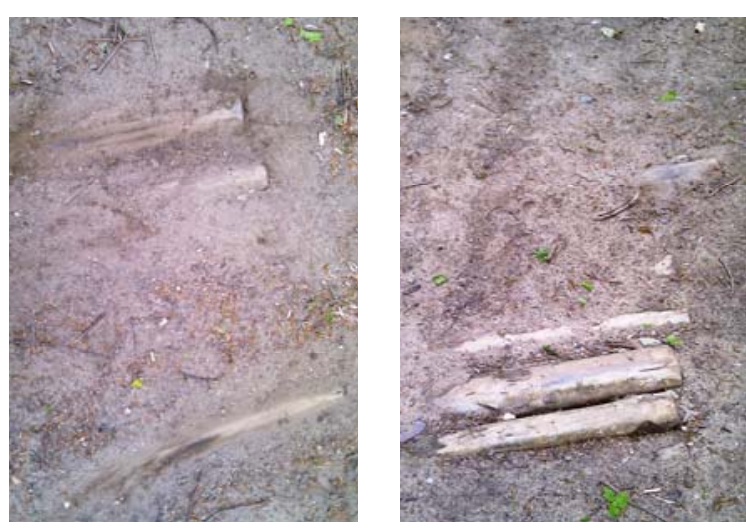

Photo 1. Pavement with shallow placed timber logs on forest road and skidder route (phot. G. Trzciński) 
Table 1. Examples of the construction of forest road pavements on a subgrade reinforced with timber logs or willow brushwood mattresses

\begin{tabular}{|c|c|c|c|}
\hline $\begin{array}{l}\text { Forest dis- } \\
\text { trict }\end{array}$ & Type of subgrade & Construction of pavement & $\begin{array}{l}\text { Year of con- } \\
\text { struction/ re- } \\
\text { construction }\end{array}$ \\
\hline Stuposiany & $\begin{array}{l}\text { medium clay on heavy clay/ } \\
\text { heavy rocky clay }\end{array}$ & $\begin{array}{l}\text { transverse logs of } 10-15 \mathrm{~cm} \text { diameter laid on five longitudinal logs of } 30 \mathrm{~cm} \\
\text { diameter filled with aggregate; } 15 \mathrm{~cm} \text { of aggregate } 0 / 63 \text { and } 10 \mathrm{~cm} \text { of aggre- } \\
\text { gate } 0 / 31.5\end{array}$ & $1991 / 1992$ \\
\hline Lutowiska & $\begin{array}{l}\text { silt loam/medium clay and } \\
\text { heavy rocky clay }\end{array}$ & transverse logs of $10-12 \mathrm{~cm}$ diameter on subsoil; $25-30 \mathrm{~cm}$ of aggregate & 1977 \\
\hline \multirow{4}{*}{ Koło } & sandy and light clay & $\begin{array}{l}\text { transverse logs of } 12-15 \mathrm{~cm} \text { diameter and } 2.6-2.8 \mathrm{~m} \text { in length; } 15 \mathrm{~cm} \text { of } 0 / 31.5 \\
\text { gravel }(3-5 \mathrm{~cm} \text { in many places) }\end{array}$ & 2011 \\
\hline & sandy and light clay & $\begin{array}{l}\text { Oak logs (tree branches) of } 5-10 \mathrm{~cm} \text { diameter covered with soil and in some } \\
\text { places aggregate }\end{array}$ & 1981 \\
\hline & clayey sand on loose sands & $\begin{array}{l}\text { transverse pine logs of } 12-16 \mathrm{~cm} \text { diameter and } 3 \mathrm{~m} \text { long filled with sand- } \\
\text { gravel (gravel) at various depths from } 3-15 \mathrm{~cm}\end{array}$ & 2012 \\
\hline & $\begin{array}{l}\text { poorly clayey sands / loose } \\
\text { sands }\end{array}$ & $\begin{array}{l}\text { transverse pine logs of } 12-16 \mathrm{~cm} \text { diameter and } 3 \mathrm{~m} \text { long filled with sand- } \\
\text { gravel (gravel) at various depths from } 3-15 \mathrm{~cm}\end{array}$ & 2012 \\
\hline \multirow{2}{*}{ Ustka } & loose sands & $\begin{array}{l}10 \mathrm{~cm} \text { of } 0 / 31.5 \text { aggregate; } 20 \mathrm{~cm} \text { of } 0 / 63 \text { aggregate; geotextile, } 20 \mathrm{~cm} \text { of ag- } \\
\text { gregate; willow brushwood mattresses } 15 \mathrm{~cm} \text { thick covered with sand }\end{array}$ & 2014 \\
\hline & $\begin{array}{l}\text { loose sands and poorly clay- } \\
\text { ey sands - clayey sands }\end{array}$ & $\begin{array}{l}\text { soil-surfaced road, sections with } 10 \mathrm{~cm} \text { thick brushwood mats covered with } \\
\text { sand }\end{array}$ & 2011 \\
\hline Olsztyn & $\begin{array}{l}\text { transition peat } \\
\text { peat soils }\end{array}$ & $\begin{array}{l}12-15 \mathrm{~cm} \text { of sand on brushwood mattresses; timber grillage (4 longitudinal } \\
\text { logs of } 13-15 \mathrm{~cm} \text { diameter and transverse logs of } 18-20 \mathrm{~cm} \text { diameter arranged } \\
\text { at } 1.5 \mathrm{~m})\end{array}$ & 1996 \\
\hline
\end{tabular}

Source: own elaboration.

With so many different pavement constructions and technological solutions, we decided to build reference test sections reinforced with timber logs and willow brushwood mattresses. We used pine and oak logs, mats made of willow and mats with a reinforced structure (timber poles placed in the middle of the mat) using different aggregates (Photos 2 and 3). Different timber logs and aggregates were used to investigate the impact on road parameters and technological and economic aspects (wood price and biodegradation).
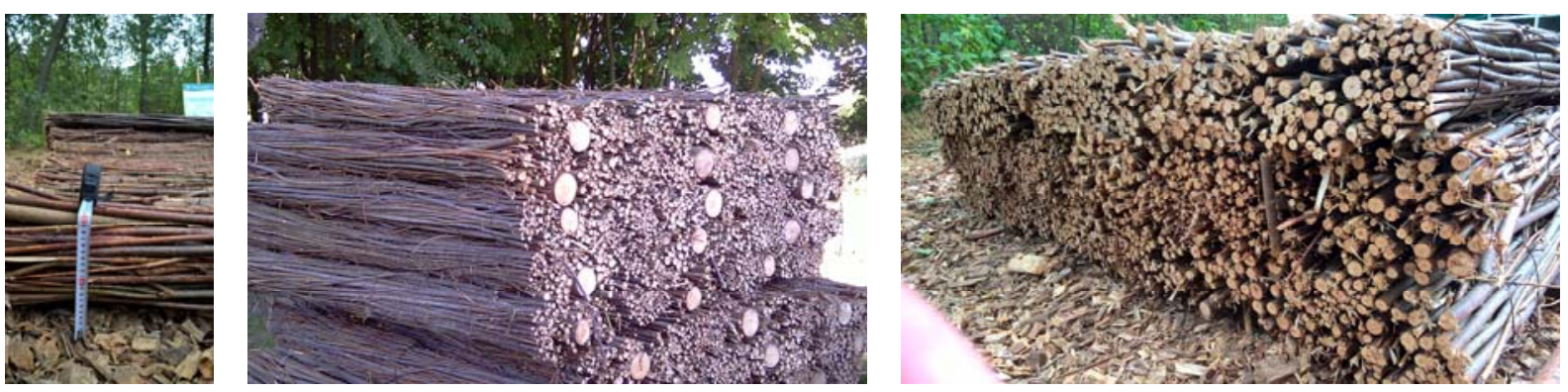

Photo 2. Willow brushwood mattress with and without logs reinforcements built in trial sections of Brzeziny Forest District (phot. G. Trzciński)

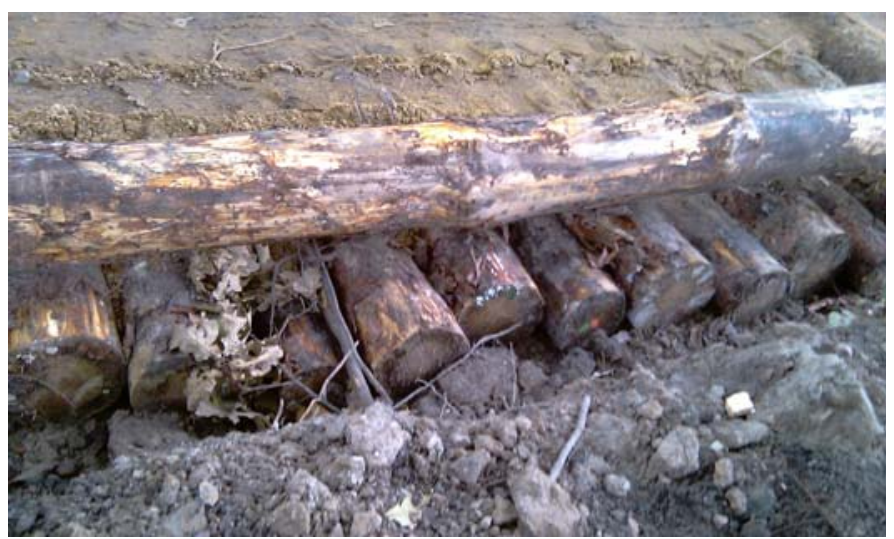

Photo 3. Oak and pine logs built in trial sections in Brzeziny Forest District (phot. G. Trzciński)

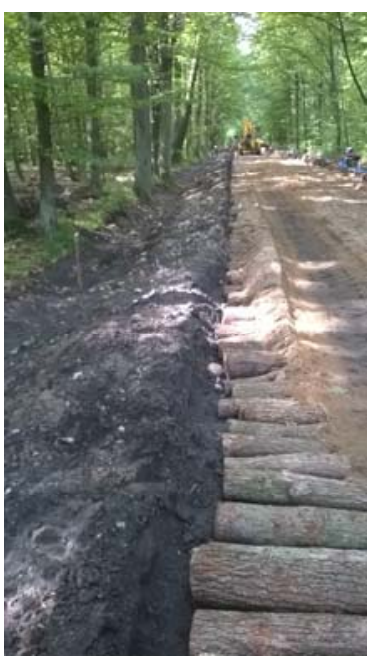


The test sections were constructed on a forest road in the Spalsko-Rogowskie Promotional Forest Complex located in the Brzeziny Forest District of the Wiączyń Forestry Division. Eight variants were built: two sections with oak logs and two sections with pine logs, three variants with willow brushwood mattresses, a comparative section made up of a fragment of the road in its current state, profiled and with a layer of sand-gravel (Tab. 2).

Table 2. Description of pavement construction built on trial sections in Brzeziny Forest District

\begin{tabular}{|c|c|}
\hline Section number & Construction of pavement \\
\hline \multirow{3}{*}{ A1 } & subgrade reinforced with oak logs of ø $12 \div 18 \mathrm{~cm}$ filled with sand \\
\hline & $20 \mathrm{~cm}$ drainage layer of coarse sand \\
\hline & pavement with $18 \mathrm{~cm}$ of $0 / 31.3$ crushed aggregate \\
\hline \multirow{3}{*}{ A2 } & subgrade reinforced with oak logs of $\varnothing 12 \div 18 \mathrm{~cm}$ filled with sand \\
\hline & $20 \mathrm{~cm}$ drainage layer of coarse sand \\
\hline & pavement with $20 \mathrm{~cm}$ of $0 / 31.5$ sand-gravel \\
\hline \multirow{3}{*}{ B1 } & subgrade reinforced with pine logs of $\varnothing 12 \div 18 \mathrm{~cm}$ filled with sand \\
\hline & $20 \mathrm{~cm}$ drainage layer of coarse sand \\
\hline & pavement with $18 \mathrm{~cm}$ of $0 / 31.3$ crushed aggregate \\
\hline \multirow{3}{*}{ B2 } & subgrade reinforced with pine logs of $ø 12 \div 18 \mathrm{~cm}$ filled with sand \\
\hline & $20 \mathrm{~cm}$ drainage layer of coarse sand \\
\hline & pavement with $20 \mathrm{~cm}$ of $0 / 31.5$ sand-gravel \\
\hline \multirow{3}{*}{$\mathrm{C} 1$} & subgrade reinforced with $20 \mathrm{~cm}$ thick $2.0 \times 2.0 \mathrm{~m}$ willow brushwood mattresses \\
\hline & $12 \mathrm{~cm}$ drainage layer of coarse sand \\
\hline & pavement with $18 \mathrm{~cm}$ of $0 / 31.3$ crushed aggregate \\
\hline \multirow{3}{*}{$\mathrm{C} 2$} & subgrade reinforced with $20 \mathrm{~cm}$ thick $2.0 \times 2.0 \mathrm{~m}$ willow brushwood mattresses strengthened with timber logs \\
\hline & $12 \mathrm{~cm}$ drainage layer of coarse sand \\
\hline & pavement with $18 \mathrm{~cm}$ of $0 / 31.5$ sand-gravel \\
\hline \multirow{5}{*}{$\mathrm{C} 3$} & subgrade reinforced with $20 \mathrm{~cm}$ thick $2.0 \times 2.0 \mathrm{~m}$ willow brushwood mattresses \\
\hline & alignment layer of $5 \mathrm{~cm}$ of sand \\
\hline & $400 \mathrm{~g} \mathrm{~m}^{-2}$ geotextile \\
\hline & $16 \mathrm{~cm}$ of $0 / 63$ sand-gravel \\
\hline & pavement with $10 \mathrm{~cm}$ of $0 / 31.5$ sand-gravel \\
\hline \multirow{2}{*}{$\mathrm{D}$} & $12 \mathrm{~cm}$ of $0 / 31.5$ crushed aggregate \\
\hline & existing pavement profiled and thickened \\
\hline
\end{tabular}

Source: own elaboration.

\section{DEFLECTION OF THE PAVEMENTS UNDER LOADS}

For the primary load, road sections reinforced with willow brushwood mattresses have a greater maximum deflection in the range of $3.95-8.22 \mathrm{~mm}$ than this reinforced with timber logs: $1.41-2.68 \mathrm{~mm}$ (Tab. 3). All sections are characterized by significant deformations of $0.92 \mathrm{~mm}$ to $4.95 \mathrm{~mm}$ after the load is removed.
For the secondary load, sections reinforced with oak and pine logs and covered with various with various types of materials had similar results, with a maximum deflection in the range of $0.60-0.93 \mathrm{~mm}$. Sections with willow brushwood mattresses reacted differently to the load and had a much greater deformation, with the largest of $4.05 \mathrm{~mm}$ found for the pavement of section C3 (Fig. 1).

Table 3. The size of deformation under primary load of the pavement of a road section in Brzeziny Forest District

\begin{tabular}{|c|c|c|c|c|c|c|c|c|c|c|c|c|c|c|c|c|}
\hline Load, MN $\cdot \mathrm{m}^{-2}$ & 0.00 & 0.00 & 0.05 & 0.10 & 0.10 & 0.15 & 0.20 & 0.20 & 0.25 & 0.30 & 0.30 & 0.35 & 0.40 & 0.45 \\
\hline Measure of deflection & \multicolumn{10}{|c|}{ Deflection with and after removing the load, mm } \\
\hline A1 & 0.00 & 0.92 & 0.14 & 0.35 & 1.27 & 0.53 & 0.68 & 1.36 & 0.84 & 0.97 & 1.40 & 1.10 & 1.28 & 1.41 \\
\hline A2 & 0.00 & 1.45 & 0.24 & 0.54 & 1.92 & 0.83 & 1.05 & 2.05 & 1.31 & 1.51 & 2.08 & 1.72 & 1.88 & 2.09 \\
\hline B1 & 0.00 & 1.40 & 0.32 & 0.65 & 1.76 & 0.97 & 1.12 & 1.91 & 1.34 & 1.48 & 1.96 & 1.65 & 1.82 & 1.98 \\
\hline B2 & 0.00 & 1.90 & 0.39 & 0.79 & 2.48 & 1.19 & 1.45 & 2.62 & 1.74 & 1.98 & 2.67 & 2.25 & 2.47 & 2.68 \\
\hline C1 & 0.00 & 2.02 & 0.40 & 0.90 & 3.21 & 1.40 & 1.79 & 3.70 & 2.30 & 2.72 & 3.92 & 3.17 & 3.53 & 3.95 \\
\hline C2 & 0.00 & 3.09 & 0.65 & 1.32 & 4.34 & 1.94 & 2.48 & 4.80 & 3.02 & 3.50 & 4.97 & 4.03 & 4.57 & 4.99 \\
\hline C3 & 0.00 & 4.85 & 0.83 & 1.86 & 7.05 & 2.96 & 3.82 & 7.68 & 4.83 & 5.60 & 8.19 & 6.56 & 7.29 & 8.22 \\
\hline D & 0.00 & 1.54 & 0.28 & 0.63 & 2.05 & 0.92 & 1.15 & 2.15 & 1.42 & 1.61 & 2.17 & 1.82 & 2.00 & 2.19 \\
\hline
\end{tabular}

Explanations: grey areas - deflection after removing the load.

Source: own study. 


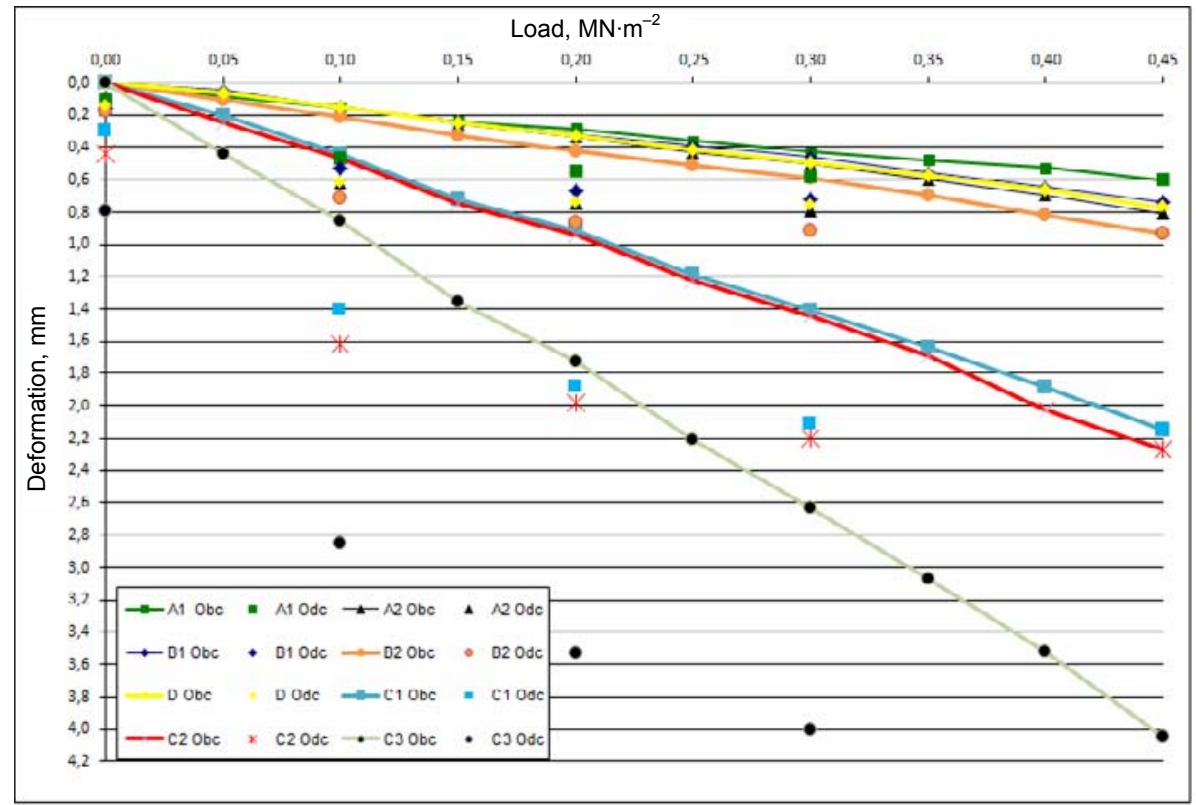

Fig. 1. The size of the deformation under the secondary load on the pavement of the trial sections; $\mathrm{Obc}=$ deflection after the load, Odc $=$ deflection after removing the load; source: own results

\section{BEARING CAPACITY OF PAVEMENT - DEFORMATION MODULI}

During the primary load, pavements with logs covered with aggregate are characterized by lower deflections than those civered with sand-gravel, having primary modulus values in the range of $68.1-86.5$ $\mathrm{MN} \cdot \mathrm{m}^{-2}$ and $40.9-68.1 \mathrm{MN} \cdot \mathrm{m}^{-2}$ respectively. The obtained secondary modulus values of 118.4-204.6 $\mathrm{MN} \cdot \mathrm{m}^{-2}$ for pavements reinforced with logs are satisfactory, most measurements attained over $120 \mathrm{MN} \cdot \mathrm{m}^{-2}$, and only the measurement of section A2 reached 107.1 MN $\cdot \mathrm{m}^{-2}$, which is the minimum value for pavements reinforced with logs (Tab. 4). Smaller dif- ferences in secondary modulus values are observed between sections using aggregate and those with sand-gravel. The secondary modulus results for surface reinforced with willow brushwood mattresses, regardless of the aggregate used or additional mat strengthening, in the range of $25.5-57.7 \mathrm{MN} \cdot \mathrm{m}^{-2}$ are low and do not meet the requirements for average transportation needs. For comparisons, measurements on the sections were made with a dynamic plate to determine the modulus of elasticity ( $E_{V D}$ Dynamic deformation modulus), which were from $64.1 \mathrm{MN} \cdot \mathrm{m}^{-2}$ to $86.5 \mathrm{MN} \cdot \mathrm{m}^{-2}$ for pavements reinforced with $\operatorname{logs}$ and $19.2-39.7 \mathrm{MN} \cdot \mathrm{m}^{-2}$ for pavements with brushwood mattresses.

Table 4. The values of primary and secondary deformation moduli and the deformation indicator for pavements of timber logs and willow brushwood mattresses

\begin{tabular}{|c|c|c|c|c|}
\hline \multirow{2}{*}{$\begin{array}{c}\text { Section - pavement } \\
\text { Reinforcement / road fill }\end{array}$} & \multicolumn{2}{|c|}{ Deformation modulus, $\mathrm{MN} \cdot \mathrm{m}^{-2}$} & \multirow{2}{*}{$\begin{array}{l}\text { Deformation } \\
\text { indicator }\end{array}$} & \multirow{2}{*}{$\begin{array}{c}\mathrm{E}_{\mathrm{VD}} \\
\mathrm{MN} \cdot \mathrm{m}^{-2}\end{array}$} \\
\hline & primary & secondary & & \\
\hline \multirow{2}{*}{$\begin{array}{c}\mathrm{A} 1 \\
\text { Oak logs / aggregate }\end{array}$} & 86.54 & 173.08 & 2.00 & 69.4 \\
\hline & 86.54 & 204.55 & 2.36 & 86.5 \\
\hline \multirow{3}{*}{$\begin{array}{c}\mathrm{A} 2 \\
\text { Oak logs / sand-gravel }\end{array}$} & 68.18 & 160.71 & 2.36 & \multirow{3}{*}{64.1} \\
\hline & 51.14 & 107.14 & 2.10 & \\
\hline & 50.00 & 140.63 & 2.81 & \\
\hline \multirow{2}{*}{$\begin{array}{c}\text { B1 } \\
\text { Pine logs/ aggregate }\end{array}$} & 75.00 & 132.35 & 1.76 & \multirow{2}{*}{75.0} \\
\hline & 68.18 & 140.63 & 2.06 & \\
\hline \multirow{2}{*}{$\begin{array}{c}\text { B2 } \\
\text { Pine logs / sand-gravel }\end{array}$} & 47.87 & 132.35 & 2.76 & 74.0 \\
\hline & 40.91 & 118.42 & 2.89 & 76.0 \\
\hline \multirow{2}{*}{$\begin{array}{c}\mathrm{C} 1 \\
\text { Willow brushwood mattresses / aggregate }\end{array}$} & 21.43 & 44.12 & 2.06 & \multirow{2}{*}{39.7} \\
\hline & 33.09 & 57.69 & 1.74 & \\
\hline \multirow{2}{*}{$\begin{array}{c}\mathrm{C} 2 \\
\text { Reinforced willow brushwood mattresses / sand-gravel }\end{array}$} & 19.40 & 45.00 & 2.32 & \multirow{2}{*}{38.3} \\
\hline & 26.16 & 52.33 & 2.00 & \\
\hline \multirow{2}{*}{$\begin{array}{c}\text { C3 } \\
\text { Willow brushwood mattresses }+ \text { geotextile / sand-gravel }\end{array}$} & 14.33 & 26.47 & 1.85 & \multirow{2}{*}{19.2} \\
\hline & 11.97 & 25.57 & 2.14 & \\
\hline \multirow{3}{*}{ Existing pavement profiled and thickened / sand-gravel } & 75.00 & 160.71 & 2.14 & 81.8 \\
\hline & 54.88 & 132.35 & 2.41 & 65.0 \\
\hline & 45.92 & 132.35 & 2.88 & 86.9 \\
\hline
\end{tabular}

Source: own study. 


\section{INDICATOR OF DEFORMATION $\boldsymbol{I}_{0}$}

The maximum value of $I_{0}$ obtained was less than 2.2 in only ten of eighteen measurements, while often the deformation moduli, particularly the secondary ones, remained low, thus providing good deformation factors, but the pavements were characterized by poor bearing capacity $(\mathrm{C} 1-\mathrm{C} 3)$. Such parameters were confirmed for pavements reinforced with willow brushwood mattresses in the Brzeziny Forest District; $I_{0}$ of $1.74-2.14$ with low values of $\mathrm{M}_{\mathrm{EII}}\left(25.5-57.7 \mathrm{MN} \cdot \mathrm{m}^{-2}\right)$. In contrast, sections with oak and pine logs with good bearing capacities of 118.4-204.5 MN'm ${ }^{-2}$ obtained unsatisfactory deformation indicators (Tab. 4).

\section{DISCUSSION}

Sections with greater thicknesses of layers in pavement construction with crushed aggregate (A1, B1) and sand-gravel (grain size is important, A2, B2) have good values of the modulus of deformation. Pavements reinforced with willow brushwood mattresses in the Brzeziny Forest District had very low values of the secondary modulus of deformation, indicating the need for further observation of the performance of these pavements during use.

Publications are lacking on the results of studies undertaken to date of the performance of forest roads using subgrades reinforced with logs or mats. In the analysis of the utility of these technologies, we compared the obtained results of the deformation moduli with the values obtained for forest roads reinforced with geosynthetics presented in the literature. The test results indicate that even on poor load bearing soils (G2, G3), reinforced with geogrids or geocells, values of $\mathrm{M}_{\mathrm{EII}}>100 \mathrm{MN} \cdot \mathrm{m}^{-2}$ could only be obtained by increasing the construction layers of the pavement [GRAJEWSKI et al. 2015; MILER et al. 2007; TRZCIŃSKI 2011a; TRZCIŃSKI et al. 2016].

The use of "standard" thickness layers on forest roads with two-layer pavements, e.g. a lower layer of 180-200 mm of coarse aggregate and an upper layer of 100-140 mm of key aggregate (or alternatively sand-gravel) would not achieve the expected value of the secondary modulus. Pavements of willow brushwood mattresses in the study sections at the Brzeziny Forest District (covered with approx. $300 \mathrm{~mm}$ of sand-gravel) perform similarly (low $\mathrm{M}_{\mathrm{EII}}$ values), whereas with aggregate thicknesses of approx. 500 $\mathrm{mm}$ over the mattresses obtain very good results.

\section{CONCLUSIONS}

The forests managed by State Forest National Forests Holding have various types of constructed forest roads with pavements reinforced with timber logs and brushwood mattresses, but in some cases, they were not built according to the guidelines of the technology used. After having conducted an in-depth comparative analysis of the technologies and their economic aspects in relation to other materials, we recommend that guidelines be developed on the use of timber materials to reinforce forest road pavements.

The results of pavement bearing capacity measurements on sections using subgrade reinforced with pine or oak logs indicate the possibility of using such solutions on forest roads. The received better results for oak logs with using crushed aggregates indicate the choice of this technology.

When designing a $350 \mathrm{~cm}$ wide road, the timber logs used should be $425 \mathrm{~cm}$ in length with a diameter of $12-18 \mathrm{~cm}$ with a sand layer of $20 \mathrm{~cm}$ and a minimum of $20 \mathrm{~cm}$ of pavement of crushed aggregate $0 / 31$ $\mathrm{mm}$.

Further observations are needed of those sections reinforced with brushwood mattresses to define their performance during use given the low values obtained of the secondary modulus of deformation, but with simultaneous low deformation indicators.

Research conducted by the Centre for Development and Implementation of National Forests in Bedoń commissioned by the Directorate General of State Forests.

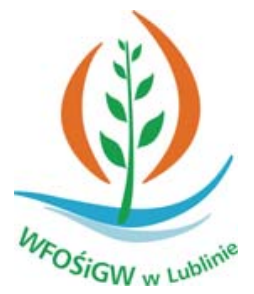

Dofinansowano ze środków Wojewódzkiego Funduszu Ochrony Środowiska i Gospodarki Wodnej w Lublinie Cofinanced by Voivodeship Fund for Environmental Protection and Water Management in Lublin

\section{REFERENCES}

BN-64/8931-02 Drogi samochodowe. Oznaczanie modułu odkształcenia nawierzchni podatnych i podłoża przez obciążenie płytą [Road car. Determination of modulus of flexible pavements and the substrate by the load plate]. Warszawa. Polski Komitet Normalizacyjny.

DZIKOWSKi J., SZARŁOWICZ A., BURZYŃSKi S., RAJSMAN M., SAtola J., Wiązowski Z. 2006. Drogi leśne - Poradnik techniczny [Forest roads: Technical guide] [online]. Warszawa, Bedoń. ORWLP, DGLP pp. 136. [Access 30.05.2017]. Available at: http://www.lasy.gov.pl/ publikacje/do-poczytania/drogi_lesne/view

GoDLEWSKi D. 2011. Nawierzchnie drogowe [Pavements of roads]. Warszawa. Oficyna Wydaw. PW. ISBN 978-837207-965-7 pp. 274.

Grajewski S. M., Czerniak A., KaszTelan A., Kayzer D., SzÓSTAKOWSKI P. 2015. Zastosowanie geotkaniny do zwiększania nośności dróg leśnych na terenach bagiennych [Application of a geotextile to increase the bearing capacity forest roads in wetlands]. Acta Scientiarum Polonorum Seria Silvarum Colendarum Ratio et Industria Lignaria. T. 14. Z. 4 p. 301-311.

JĘDRYKA E. 2007. Budowle wodne $\mathrm{z}$ naturalnych materiałów [Water constructions made of natural materials]. Woda-Środowisko-Obszary Wiejskie. T. 7. Z. 2 b (21) p. $55-74$.

KAMIŃSKI B., CZERNIAK A. 2001. Wpływ podłoża gruntowego na nośność nawierzchni thuczniowych [The impact of the ground on bearing capacity the pavements 
broken stone]. Prace Komisji Nauk Rolniczych i Komisji Nauk Leśnych PTPN. T. 90. ISSN 0079-4708 p. 4759.

KozŁowsKi W., Surowiecki A. 2011. Kierunki rozwoju konstrukcji nawierzchni dróg wiejskich [Development directions in construction of pavement on the country roads]. Problemy Inżynierii Rolniczej. Nr 1 p. 173-183.

MARTIN A.M., OWENDE P.M.O., O'MAHONY M.J., WARD S.M. 1999. Estimation of the serviceability of forest access roads. Journal of Forest Engineering. Vol. 10 p. 55-61.

Miler A.T., CzerniaK A., Grajewski S., KamińsKi B., OKOŃSKI B. 2007. Marshlands of "Lasy Rychtalskie" forest promotion complex - Present state and perspective of changes. Infrastructure and Ecology of Rural Areas. Nr 3 p. 21-36.

MunRo R. 2004. Dealing with bearing capacity problems on low volume roads constructed on peat [online]. ROADEX II Project. Scotland. [Access 20.12.2016]. Available at: http://www.roadex.org/wp-content/ uploads/2014/01/2_5-Roads-on-Peat_1.pdf
O’Mahony M.J., Ueberschaer A., OWende P.M.O., Ward S.M. 2000. Bearing capacity of forest access roads built on peat soils. Journal of Terramechanics. Vol. 37 p. $127-138$.

PN-S-02205. 1998. Drogi samochodowe. Roboty ziemne. Wymagania i badania [Road car. Earthworks. Requirements and testing]. Warszawa. PKN.

TRZCIŃSKI G. 2011a. Analiza parametrów technicznych dróg leśnych w aspekcie wywozu drewna samochodami wysokotonażowymi [Analysis of technical parameters of forest roads in terms on timber haulage by hightonnage vehicles]. Warszawa. Wydaw. SGGW. ISBN 978-83-7583-291-1 pp. 128.

TRZciŃSKi G. 2011b. Wywóz drewna wielkowymiarowego a obciążenie dróg leśnych [Impact of the timber haulage on loading of the forest roads]. Problemy Inżynierii Rolniczej. Nr 1 p. 185-193.

Trzciński G., CZERniak A., Grajewski S. 2016. Funkcjonowanie infrastruktury komunikacyjnej obszarów leśnych [The functioning of forest communication infrastructure]. Infrastruktura i Ekologia Terenów Wiejskich $\mathrm{Nr}$ II/2/2016 p. 527-542.

\section{Grzegorz TRZCIŃSKI, Pawel KOZAKIEWICZ, Rafal SELWAKOWSKI}

\section{Techniczne aspekty użycia drewna w budowie dróg leśnych}

\section{STRESZCZENIE}

Podstawą do podjęcia tematu badań były aspekty ekologiczne oraz zainteresowanie jednostek Państwowego Gospodarstwa Leśnego "Lasy Państwowe" (PGL LP) wzmacnianiem podłoża gruntowego materiałem z drewna (wałki, maty). Celem pracy było przeprowadzenie analizy parametrów technicznych dróg leśnych wykonanych na podłożu wzmocnionym wałkami drewnianymi (żerdziami) lub matami wierzbowymi. W ramach prac badawczych określono zakres stosowania w jednostkach PGL LP rozwiązań omawianej technologii oraz parametrów dróg leśnych istniejących $w$ nadleśnictwach wykonanych na podbudowie $\mathrm{z}$ drewna (wałków i mat). W ramach badań zaprojektowano i wykonano drogę z wzorcowymi odcinkami w różnych wariantach podłoża wzmocnionego wałkami (dębowymi, sosnowymi) i matami wierzbowymi. Do analiz wybrano parametry techniczne zapewniające cechy użytkowe między innymi nośność nawierzchni. Zdolność badanych nawierzchni do przyjmowania obciążeń od kół pojazdów została określona na podstawie ugięcia nawierzchni oraz pierwotnego (MEI) i wtórnego (MEII) modułu odkształcenia z obliczonym wskaźnikiem odkształcenia $\left(I_{0}\right)$. Oznaczenie modułu odkształceń ME nawierzchni i podłoża drogowego wykonano z zastosowaniem płyty VSS o średnicy $300 \mathrm{~mm}$. Otrzymano dużą rozpiętość wyników wtórnego modułu odkształcenia nawierzchni na wałkach drewnianych (107-204 MN·m $\left.{ }^{-2}\right)$ i na matach wierzbowych $\left(26-58 \mathrm{MN} \cdot \mathrm{m}^{-2}\right)$, co było uzależnione głównie od średnicy zastosowanych wałków i sposobu ich ułożenia oraz użytego kruszywa.

Słowa kluczowe: drogi leśne, nawierzchnia drogi, podłoże drogowe, wzmocnienie podłoża drogowego 